University of Nebraska - Lincoln

DigitalCommons@University of Nebraska - Lincoln

Agronomy \& Horticulture -- Faculty Publications

Agronomy and Horticulture Department

January 1985

Response of an Irrigated Cool- and Warm- Season Grass Mixture to Nitrogen and Harvest Scheme

Joseph L. Petersen

Texas A\&M University, San Angelo

Lowell E. Moser

University of Nebraska-Lincoln, Imoser1@unl.edu

Follow this and additional works at: https://digitalcommons.unl.edu/agronomyfacpub

Part of the Plant Sciences Commons

Petersen, Joseph L. and Moser, Lowell E., "Response of an Irrigated Cool- and Warm- Season Grass Mixture to Nitrogen and Harvest Scheme" (1985). Agronomy \& Horticulture -- Faculty Publications. 52. https://digitalcommons.unl.edu/agronomyfacpub/52

This Article is brought to you for free and open access by the Agronomy and Horticulture Department at DigitalCommons@University of Nebraska - Lincoln. It has been accepted for inclusion in Agronomy \& Horticulture -Faculty Publications by an authorized administrator of DigitalCommons@University of Nebraska - Lincoln. 


\title{
Response of an Irrigated Cool- and Warm- Season Grass Mixture to Nitrogen and Harvest Scheme
}

\author{
JOSEPH L. PETERSEN AND LOWELL E. MOSER
}

\begin{abstract}
Maintaining a mixture of cool-and warm-season grasses under intensive management for season-long production is difficult, due to species shifts, especially to a dominance of cool-season grasses when heavy amounts of nitrogen $(N)$ fertilizer are used. The objective of this study was to determine if high forage yields could be produced season long while maintaining a desirable balance of warm-and cool-season grasses.

The study was conducted near Mead, Nebraska on a Sharpsburg silty clay loam (Typic Argiudoll). An irrigated mixture of 3 warmseason grasses and 1 cool-season grass, big bluestem (A ndropogon gerardii Vitman), switchgrass (Panicum virgatum L.), and indiangrass [Sorghastrum nutans (L.) Nash] and smooth brome (Bromus inermis Leyss.) was fertilized at low (150 kg/ha), medium (250 $\mathrm{kg} / \mathrm{ha})$ and high $(350 \mathrm{~kg} / \mathrm{ha})$ rates of $\mathrm{N}$ in split applications. Three harvest schemes were designed to either produce high quality forage or to maximize yield.

Herbage yields showed a quadratic response with $\mathrm{N}$ level. A late May/mid July harvest scheme for the first and second cuttings did not produce as much forage as late May/late August or early June/late August harvest schemes. Population of smooth brome and other cool-season grasses declined with the higher $\mathbf{N}$ rates. Populations of warm-season grasses were not greatly affected by $\mathbf{N}$ level. Density of smooth brome increased under all harvest scheme treatments and the highest increase for other cool-season grasses was with a May 24/July 13 harvest scheme. Warm-season grasses maintained a steady density over the 3 years. Forage was produced from early May until late summer with an irrigated cool- and warm-season mixture. Fall production of smooth brome was minimal, although stand was generally maintained. Nitrate $\mathbf{N}$ accumulated in the soil under the medium and high $\mathbf{N}$ treatments.
\end{abstract}

Authors are formerly graduate student, Department of Agronomy, University of Nebraska-Lincoln, currently research associate, Texas A\&M University Agricultural Research and Extension Center, Route 2, Box 950, San Angelo, Texas 76901; and professor, Department of Agronomy, University of Nebraska-Lincoln, Lincoln 68583-0910.

This article is a contribution from the Department of Agronomy. University of Nebraska-Lincoln, published with the approval of the Director of the Nebraska Agricultural Experiment Station Journal Series paper number 7394.

Manuscript accepted March 26, 1984.
Cool- or warm-season grass pastures generally have a relatively short period of active production in the central Plains states. In eastern Nebraska, perennial cool-season grasses initiate growth in April, mature early to mid-June, and produce regrowth in September and October. Growth of warm-season grasses begins about mid-May and they reach maturity in late August. Since warmseason grasses are dormant until late May, there is little soil water depletion in the early spring. In order to distribute high quality forage throughout the grazing season a producer needs both cooland warm-season grasses.

Seeding a mixture of cool-and warm-season grasses generally has not been recommended. Warnes et al. (1971), suggested that the inclusion of cool-season grasses in a mixture of warm-season grasses would decrease maximum production. Ruminant animals are selective grazers, and in a grass mixture they have a free choice of plants, making it difficult to obtain full use of each species in the proper season (Conard and Youngman 1965). Nitrogen (N) supplied in early spring generally favors cool-season species which utilize the early season soil moisture and lessen the competitive ability of warm-season grasses (Owensby et al. 1970, Warnes et al. 1971, Rehm et al. 1976). Therefore, cool-season species will soon dominate. If water can be supplied to warm-season grasses in the summer, vegetative composition shifts might be minimized, while maintaining high yields of the grasses.

Nitrogen fertilizer has increased the yield of both smooth brome (Bromus inermis Leyss.) (Colville et al. 1963; Paulsen and Smith 1968) and warm-season prairie grasses (Rehm et al. 1972, Hall et al. 1982). Harvesting grasses at early morphological stages generally results in lower yields than when harvested at later stages. Total dry matter yields of smooth brome increased when cutting was delayed until early anthesis and declined when clipped during stem elongation (Knievel et al. 1971, Kunelius et al. 1974). In a study conducted in the Missouri Ozarks, harvesting of 3 warm-season grasses at the seed-ripened stage or later increased yields. Foliage removal when flowering stalks were starting to form (late July) decreased yields and stand persistence (Vogel and Bjugstad 1968). 
The objective of this research was to determine if herbage production for a mixture of cool- and warm-season grasses would be possible for the entire growing season if supplied with nitrogen and water and harvested appropriately. A related objective was to determine if warm-season grasses would maintain their density in the presence of a cool-season grass under high levels of nitrogen when water was not limiting.

\section{Materials and Methods}

The study was conducted on an established mixture of warmand cool-season perennial grasses at the University of Nebraska Field Laboratory near Mead, Neb., approximately $52 \mathrm{~km}$ northeast of Lincoln, Neb. The annual precipitation averages $76 \mathrm{~cm}$ with approximately $75 \%$ falling during the growing season. The grasses, seeded in 1967 on a Sharpsburg silty clay loam (Typic Argiudoll) included 3 warm-season grasses: big bluestem (Andropogon gerardii Vitman), indiangrass [Sorghastrum nutans (L.) Nash], switchgrass (Panicum virgatum L.), and 1 cool-season grass: smooth brome. Three $N$ rates combined with 3 harvest schemes $(3 \times 3$ factorial) were replicated 4 times in a randomized complete block design. Individual plots were $2.75 \times 6.10 \mathrm{~m}\left(16.8 \mathrm{~m}^{2}\right)$.

Prior to spring growth in 1978, old growth was removed, leaving a stubble approximately $7.6 \mathrm{~cm}$ high. Sixty-seven $\mathrm{kg} /$ ha phosphorus $\left(\mathrm{P}_{2} \mathrm{O}_{5}\right)$ was applied to all plots on April 1, 1978. Broadcast $\mathrm{N}$ as ammonium nitrate $\left(\mathrm{NH}_{4} \mathrm{NO}_{3}\right)$ and harvest scheme treatments were applied in 1978 and 1979 (Table 1). Grass was irrigated during both

Table 1. Nitrogen rates and harvest scheme treatments applied in 1978 and 1979.

\begin{tabular}{|c|c|c|c|}
\hline \multirow[b]{2}{*}{ Date of application } & \multicolumn{2}{|c|}{ Nitrogen rate $(\mathrm{kg} / \mathrm{ha})$} & \multirow[b]{2}{*}{ High } \\
\hline & Low & Medium & \\
\hline \multirow[t]{2}{*}{$\begin{array}{l}\text { April 1 } \\
\text { June } 10 \\
\text { Sept. } 1 \\
\text { Total N }\end{array}$} & $\begin{array}{r}50 \\
50 \\
50 \\
150\end{array}$ & $\begin{array}{r}100 \\
75 \\
75 \\
250\end{array}$ & $\begin{array}{l}150 \\
100 \\
100 \\
350\end{array}$ \\
\hline & \multicolumn{2}{|c|}{ Dates of Harvest } & \\
\hline Harvest scheme & First cut & Second cut & Third cut \\
\hline $\begin{array}{l}1 \\
2 \\
3\end{array}$ & $\begin{array}{l}\text { May 24 } \\
\text { May 31 } \\
\text { June } 6\end{array}$ & $\begin{array}{l}\text { July } 13 \\
\text { August } 28 \\
\text { August } 28\end{array}$ & $\begin{array}{l}\text { November } 7 \\
\text { November } 7 \\
\text { November } 7\end{array}$ \\
\hline
\end{tabular}

growing seasons with a sprinkler irrigation system. Irrigation scheduling was based on soil moisture observations and precipitation records at the Mead Field Laboratory. The total amount of water (precipitation and irrigation water) received by the plots was 102 and $123 \mathrm{~cm}$ for 1978 and 1979, respectively. Annual and broadleaf weeds were controlled by the application of DCPA dimethyl tetrachloroterephthalate) at $11.2 \mathrm{~kg} / \mathrm{ha}$ and $2,4-\mathrm{D}[(2,4-$ dichlorophenoxy)acetic acid] at $1.2 \mathrm{~kg} / \mathrm{ha}$ both years.

Soil samples were taken at the end of the 1978 and 1979 growing seasons to a depth of $90 \mathrm{~cm}$. Soil nitrate $\mathrm{N}$ determinations were made at $30-\mathrm{cm}$ increments to a depth of $90 \mathrm{~cm}$ and estimated for a 180-cm profile as follows: (0.118) (sampling depth $\mathrm{cm})(\mathrm{N} \mathrm{ppm})$ (1.12) $/ 0.7=\mathrm{kg} / \mathrm{ha}$ (Knudson, personal communciations 1980).

To determine forage dry matter yields, a $0.81 \times 5.2$-meter strip was harvested in the center of each plot at a $7.6 \mathrm{~cm}$ height (Table 1). A subsample was taken, weighed immediately, and dried to a constant weight in a $75^{\circ} \mathrm{C}$ forced air oven to determine moisture content.

Botanical density was determined during the third week of June in 1978, 1979, and 1980. The vegetation analysis was conducted after there was 8 to $25 \mathrm{~cm}$ regrowth following the completion of the spring harvest when the cool-season grasses had matured and the warm-season grasses had initiated vegetative growth. Estimates of density were obtained by modifying methods described by Anderson (1942). A line with 6 evenly spaced rings attached was stretched at 5 randomly selected positions across each plot. A $1-\mathrm{m}$ rod marked with $1-\mathrm{cm}$ increments was inserted into the vegetation under each ring. Stem base occurrence in a $1-\mathrm{cm}$ wide area was determined along the rods.

A multivariate procedure was used for a mean vector statistical analysis of the botanical density. Mean vectors were determined for 5 groups of vegetation: smooth brome, other cool-season perennial grasses, warm-season perennial grasses, perennial and annual forbs, and annual grasses. A Wilks' Lambda Criterion Test was used to evaluate the change in density over time (Morrison 1976). Total dry matter yields were averaged over 1978 and 1979 because there was no treatment by year interaction. Orthogonal comparisons were performed to evaluate yields as affected by harvest scheme $(p<.05)$ and the nature of the response curve of $N$ treatments (Steel and Torrie 1980). With 3 levels of nitrogen, the response must be either linear or quadratic (nonlinear).

\section{Results and Discussion}

Forage production was about $1,000 \mathrm{~kg} /$ ha greater $(p<.01)$ in 1978 than in 1979 when averaged over all treatments. Lorenz and Rogler (1967) reported there was more initial vigor the first year of fertilizer application than in succeeding years. In addition, intensive harvest management in 1978 may have lowered the yields of grasses in 1979.

Harvest scheme (HS) affected yields more than did $\mathrm{N}$ treatments. Total dry matter yields for HSI were lower $(p<.05)$ than the average of HS2 and HS3. HS3 plots also yielded more dry matter than HS2 plots (Fig. 1). The primary component for the first

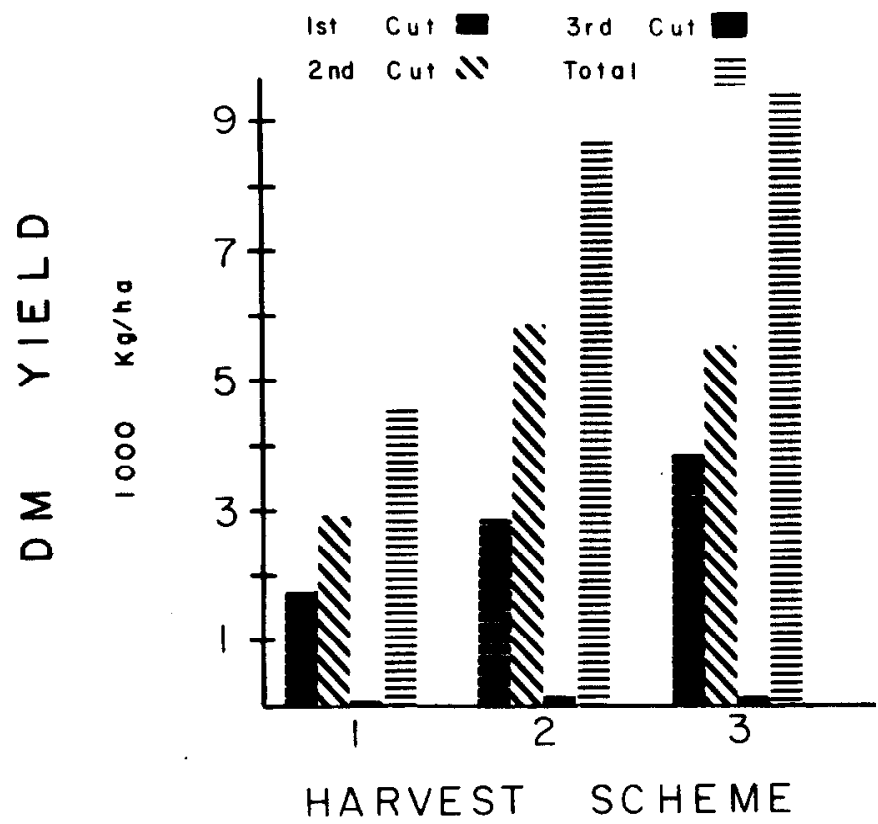

Fig. 1. Dry matter (DM) yields of forage grasses averaged over 1978 and 1979, as affected by harvest scheme. Yields for each of the 3 harvest dates and a total are shown. Harvest scheme 1 (cut May 24, July 13, Nov. 7), harvest scheme 2 (cut May 31, Aug. 28, and Nov. 7), and harvest scheme 3 (cut June 6, Aug. 28, and Nov. 7). Orthogonal contrasts for total yields show that HSI is different than an average of HS2 and HS3. Total yield for $\mathrm{HS} 2$ was less than for $\mathrm{HS} 3$.

cutting was smooth brome. The first cut for HS2, (about May 31, 1 week later than HS1), yielded about $1,100 \mathrm{~kg} /$ ha more than HSI. When the first cutting was delayed until June (HS3), first harvest yields were 2,100 and $1,000 \mathrm{~kg} / \mathrm{ha}$ greater than those of $\mathrm{HS} 1$ and 2 , respectively (Fig. 1). Warm-season grasses largely comprised the second cutting, taken July 13, for HS1 and August 28, for HS2 and HS3. The 6-week delay in harvest for HS2 and HS3 compared to 
HS1 increased yields more than $2,000 \mathrm{~kg} /$ ha for the warm-season component. Regrowth for HSI, between July 13 and August 28, was not large enough to measure in 1978 and was estimated to be about $300 \mathrm{~kg} / \mathrm{ha}$ in 1979 .

Yields for a third and final harvest in early November were low for all treatments both years (Fig. 1,2). Smooth brome was present

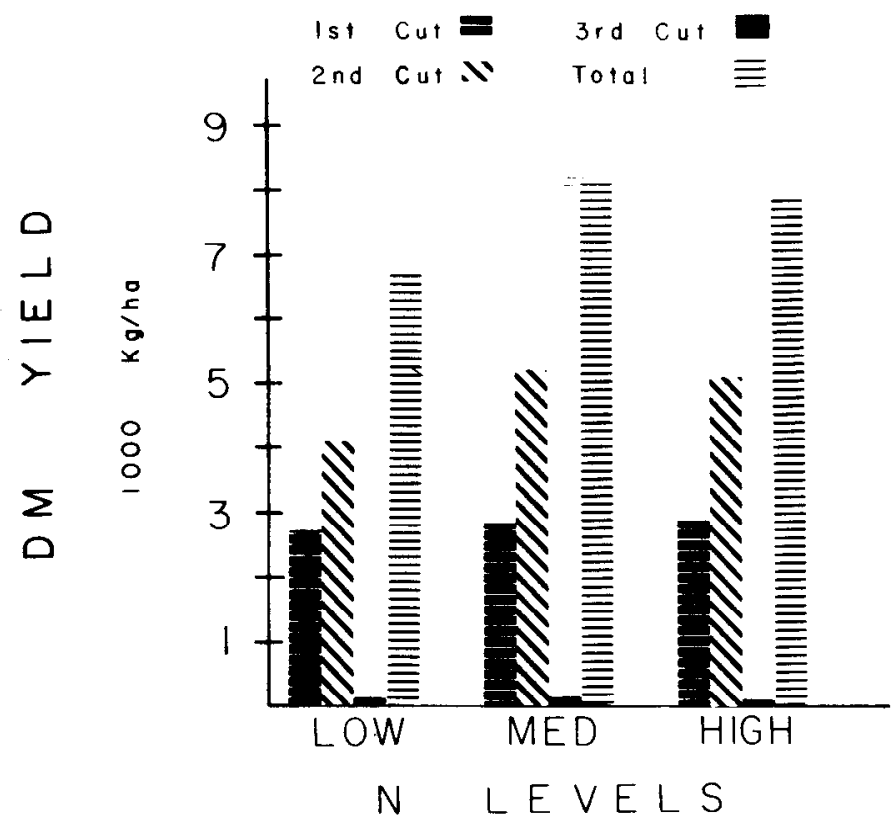

Fig. 2. Dry matter (DM) yields of forage grasses averaged over 1978 and 1979, as affected by low (150 kg/ ha ), medium ( $250 \mathrm{~kg} / \mathrm{ha}$ ), and high (350 $\mathrm{kg} / \mathrm{ha}$ ) levels of nitrogen. Each $\mathrm{N}$ treatment shows yields for 3 harvests and a total yield. Orthogonal contrasts on total yield indicate a quadratic relationship with $N$ level.

during the autumn but it did not respond to additional $\mathrm{N}$, moisture, and cool temperatures. However, the herbage was a darker green color with higher $\mathrm{N}$ rates. The intense competition of the $\mathrm{N}$-stimulated warm-season grasses during the summer may have caused the smooth brome to utilize reserve carbohydrates during summer dormancy in order to survive. Consequently, the vigor of the smooth brome was low in the autumn. Evidently, sufficient carbohydrate reserves were stored in the fall to initiate spring growth of smooth brome in 1979 and 1980.

Orthogonal contrasts between the $\mathrm{N}$ levels revealed a quadratic relationship for total yield (Fig. 2). Dry matter yields apparently peaked with about $250 \mathrm{~kg} / \mathrm{ha} \mathrm{N}$. Application of $\mathrm{N}$ in excess of 250 $\mathrm{kg}$ / ha did not increase yields further. The $\mathrm{N}$ by year interaction was not significant for the first cutting of the season. High yields were obtained all $\mathrm{N}$ rates the first year of application, probably because the plots had not received intensive management previously. The heavy rates of $\mathrm{N}$ and competition from vigorous warm-scason grasses in 1978 may have caused a decline of carbohydrate reserves in the smooth brome (White 1973).

Yields, of the predominantly warm-season grasses at the second cutting, increased about $1,000 \mathrm{~kg} /$ ha from the low to the higher $N$ rates in 1978 and 1979. Since shoot apices were not removed from the warm-season species in the first cutting, plants were able to respond to nitrogen and water. For all $\mathrm{N}$ rates summer harvests which contained predominately warm-season grasses were higher yielding than the spring or fall harvests which contained predominately smooth brome.

\section{Species Density}

The vegetation was grouped into 5 categories to be evaluated with a vector analysis using a Wilks' Lambda Criterion Test. The categories were smooth brome, other cool-season perennial grasses, warm-seasonal perennial grasses, annual and perennial forbs, and annual grasses. Because weeds respond well to additional $\mathrm{N}$ and water (Huffine and Elder 1960), plots were sprayed with DCPA and 2,4-D in 1978 and 1979 to control annual grass and broadleaf weeds, respectively. As a result, forbs were reduced from 1978-80, and the analysis of variance was not significant for annual grasses (data not shown). Wilks'Lambda Criterion Test indicated that the year by harvest scheme interaction was significant $(p<05)$ for smooth brome, other cool-season grasses, and warm-season grasses. This demonstrated that the response of density to harvest scheme differed among years (Fig. 3). The response of $\mathrm{N}$ treat-
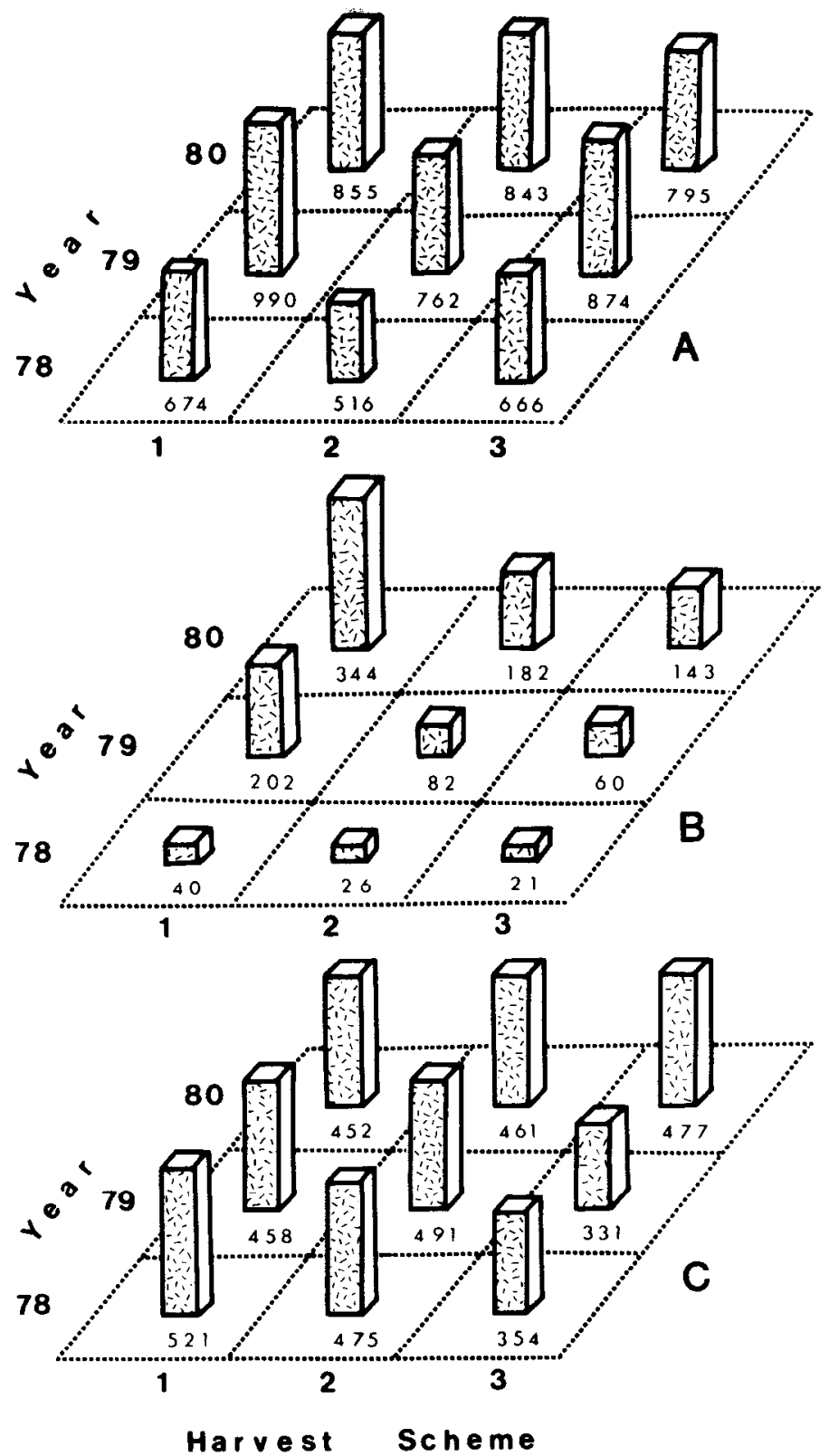

Fig. 3. Density of smooth brome $(A)$, cool-season grasses other than smooth brome (B), and warm-season grasses (C) in no. of shoots $/ \mathrm{m}^{2}$, over 3 years, as affected by harvest scheme 1 (cut May 24, July 13, No. 7), harvest scheme 2 (cut May 31, Aug. 28, Nov. 7), and harvest scheme 3 (cut June 6, Aug. 28, Nov. 7).

ments was similar each year and has been evaluated within each vegetation group on the 3-year average since there was no interaction with year (Fig. 4).

Density of smooth brome and other cool-season grasses increased from 1978 to 1980 , under all harvest scheme treatments (Figs. 3A 


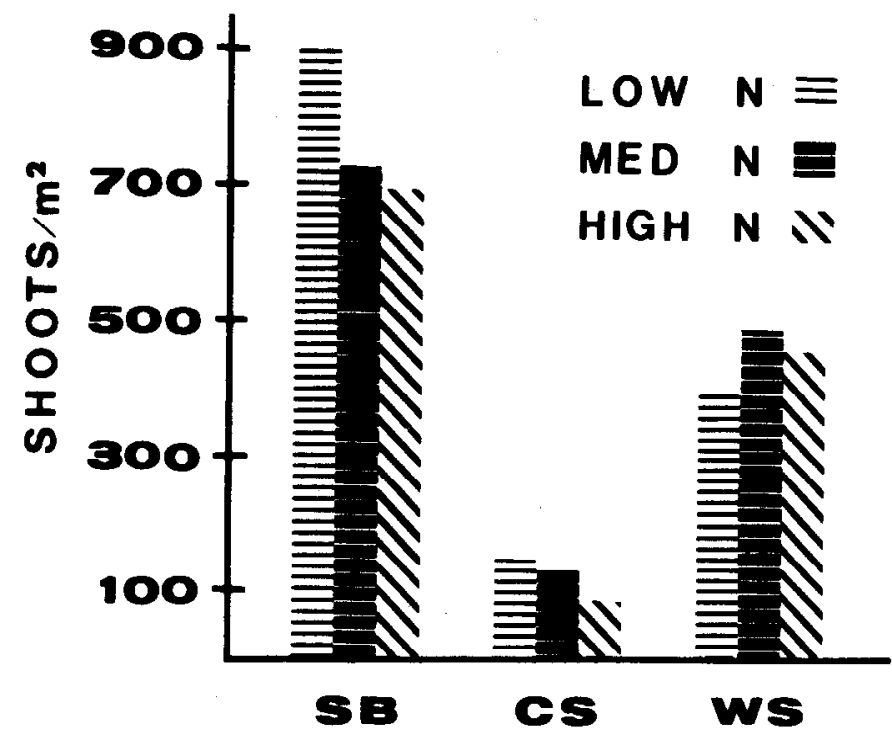

Fig. 4. Average number of shoots $/ \mathrm{m}^{2}$ in mid-June for $1978-1980$ for low $(150 \mathrm{~kg} / \mathrm{ha})$, medium $(250 \mathrm{~kg} / \mathrm{ha})$, and high $(350 \mathrm{~kg} / \mathrm{ha})$ nitrogen levels for the plant groups: smooth brome (SB), perennial cool-season grasses other than smooth brome (CS), and perennial warm-season grasses (WS). Orthogonal contrasts indicated that there is a significant $(\mathrm{p}<.05)$ linear response of $S B$ to $N$ level and there are no detectable trends $(\mathrm{p}<.05) \mathrm{CS}$ or $\mathrm{WS}$.

and 3B). Tiller growth may have been promoted by $\mathrm{N}$, irrigation, and the removal of several years of accumulated mulch, prior to initiation of the study. Increases for smooth brome were greatest from 1978 to 1979 and evidently plateaued as only HS2 had a slight increase in 1980. Kentucky bluegrass (Poa pratensis L.) was the main component of the cool-season species group. The population increased more than 8-fold under HS 1 for the 3 years and a 7 -fold increase occurred for HS2 and 3. The shoot apices for some warmseason grasses were possibly clipped with the July 13 harvest under HS 1, reducing the competitive ability of those plants much earlier than with HS2 or 3, which were clipped in late August.

Warm-season grass density decreased slightly with HS1, remained fairly constant or increased with late cutting dates, which agrees with Conard and Arthaud (1957). Harvest scheme 2 and 3 allowed nearly full development of the warm-season species, which produced severe competition with the dormant cool-season grasses.

There was a significant $(p<.05)$ linear decline in smooth brome as nitrogen level increased (Fig. 4). No significant trend in density was detected with the other cool-season grasses. Likewise no significant $(p<05)$ linear or quadratic trend was detected for the warmseason grasses (Fig. 4). Smooth brome makes little summer growth, preventing a high buildup of the carbohydrate supply. Excess $\mathrm{N}$ may have depleted the carbohydrate reserves before they could be replenished. McKee et al. (1967) suggested that at high $\mathbf{N}$ rates, stands of spring grown grass were thinned if clipped after flowering. The drastic change in microclimate at time of cutting may have killed some brome shoots.

\section{Soil Nitrate Nitrogen}

Orthogonal contrasts indicated a linear relationship between the estimated soil nitrate for a $180-\mathrm{cm}$ soil profile and $\mathbf{N}$ fertilizer level in 1978 and 1979. The highest residual nitrate level was contained in the first 30-cm increment for all $\mathrm{N}$ rates and declined with depth (Table 2). The decline was linear in 1978 but by the end of 1979 , the $30-60$ and $60-90 \mathrm{~cm}$ depths had accumulated almost as much soil nitrate as the top $30 \mathrm{~cm}$. Residual nitrate for the estimated $180 \mathrm{~cm}$ depth increased slightly between 1978 and 1979 for the low $\mathrm{N}$ rate. However, soil nitrate increased 25 and $21 \mathrm{~kg} / \mathrm{ha}$, respectively, under the medium and high $\mathrm{N}$ rates. The leaching of excess nitrate to the lower depths was probably hastened by irrigation. The high
Täble 2. Soil nitrate nitrogen (kg/ha) present in November of 1978 and 1979 , under low $(150 \mathrm{~kg} / \mathrm{ha})$, medium $(250 \mathrm{~kg} / \mathrm{ha})$, and high $(350 \mathrm{~kg} / \mathrm{ha})$ nitrogen fertilization rates averaged over harvest schemes. Confidence intervals are indicated at $(p<.05)$.

\begin{tabular}{lcrcc}
\hline \hline & Soil depth & \multicolumn{3}{c}{ Nitrate nitrogen $(\mathrm{kg} / \mathrm{ha})$} \\
\cline { 3 - 5 } Year & $(\mathrm{cm})$ & \multicolumn{1}{c}{ Low N } & Medium N & High N \\
\hline 1978 & $0-30$ & $8 \pm 1.9$ & $12 \pm 6.9$ & $28 \pm 19.3$ \\
& $30-60$ & $4 \pm 3.0$ & $9 \pm 4.8$ & $12 \pm 8.0$ \\
& $60-90$ & $3 \pm 0.3$ & $4 \pm 1.0$ & $6 \pm 2.7$ \\
& 180 cm estimate & $21 \pm 3.3$ & $31 \pm 17.3$ & $66 \pm 41.5$ \\
1979 & $0-30$ & $6 \pm 0.8$ & $17 \pm 10.9$ & $23 \pm 8.9$ \\
& $30-60$ & $6 \pm 1.7$ & $15 \pm 8.8$ & $21 \pm 4.6$ \\
& $60-90$ & $5 \pm 2.6$ & $12 \pm 3.2$ & $18 \pm 6.7$ \\
& 180 cm estimate & $25 \pm 3.3$ & $56 \pm 39.2$ & $87 \pm 27.0$ \\
\hline
\end{tabular}

residual soil nitrates at the medium and high $\mathrm{N}$ fertilizer rates were not surprising. These $\mathrm{N}$ fertilizer treatments included a September 1 application of 75 and $100 \mathrm{~kg} / \mathrm{ha} \mathrm{N}$, respectively. Since little forage was produced in the fall and soil samples were taken in November, the applied $\mathrm{N}$ accumulated in the profile.

\section{Conclusion}

With the application of medium to high levels of $\mathbf{N}$, a hay harvesting scheme, and irrigation, a mixture of warm- and coolseason grasses was maintained over a 3-year period. Although spring and summer production could be maintained with mixed warm- and cool-season grasses, fall growth of smooth brome was rather weak. This was probably due to severe competition during the summer in this hay harvesting situation. However, the following spring smooth brome had regained its vigor. Pasture studies are needed to determine whether putting a warm-season grass component in a cool-season grass mixture would increase livestock production or simplify grazing management compared to maintaining separate cool- and warm-season pastures under irrigated conditions. In situations where $\mathrm{N}$ fertilization causes a shift from warmseason to cool-season species, soil moisture plays an important role. In this study where soil moisture was maintained during the summer through irrigation, the warm-season grasses were not overtaken by cool-season grasses. Repeated applications of $\mathrm{N}$ at 250 and $350 \mathrm{~kg} /$ ha may be excessive, since residual nitrogen accumulated in the soil in the second year under both of these treatments.

\section{Literature Cited}

Anderson, Kling. L. 1942. A comparison of line transects and permanent quadrates in evaluating composition and density of pasture vegetation of the tall grass prairie type. Agron. J. 34:805-822.

Colville, W.L., Leon Chesnin, and D.P. McGill. 1963. Effect of precipitation and long term nitrogen fertilization on nitrogen uptake, crude protein content, and yield of bromegrass forage. Agron. J. 55:215-218.

Conard, E.C., and V.H. Arthaud. 1957. Effect of time of cutting on yield and botanical composition of prairie hay in southeastern Nebraska. Univ. Nebr. Agr. Exp. Sta. Bull. 184.

Conard, E.C., and V.E. Youngman. 1965. Soil moisture conditions under pastures of cool-season and warm-season grasses. J. Range Manage. 18:74-78.

Hall, K.E., J.R. George, and R.R. Riedl. 1982. Herbage dry matter yields of switchgrass, big bluestem, and indiangrass with $\mathbf{N}$ fertilization. Agron J. 74:47-51.

Huffine, W.W., and W.C. Elder. 1960. Effect of fertilization on native grass pastures in Oklahoma. J. Range Manage. 13:34-36.

Knievel, D.P., A.V.A. Jacques, and Dale Smith. 1971. Influence of growth stage and stubble height on herbage yields and persistence of smooth bromegrass and timothy. Agron. J. 63:430-434. 
Kunelius, H.T., L.B. MacLeod, and F.W. Calder. 1974. Effects of cutting management on yields, digestiblity, crude protein and persistence of timothy, bromegrass, and orchard grass. Canadian J. Plant Sci. 54:55-64.

Lorenz, R.J., and G.A. Rogler. 1967. Grazing and fertilization affect root development of range grasses. J. Range Manage. 20:129-132.

McKee, W.H., Jr., and R.H. Brown, and R.H. Blaser. 1967. Effect of clipping and nitrogen fertilization on yield and stands of tall fescue. Crop Sci. 7:567-570.

Morrison, D.F. 1976. Multivariate statistical methods. McGraw-Hill Book Co., New York.

Owensby, C.E., R.M. Hyde, and K.L. Anderson. 1970. Effects of clipping and supplemental nitrogen and water on loamy upland bluestem range. J. Range Manage. 23:341-346.

Paulsen, G.M., and Dale. Smith. 1968. Influences of several management practices on growth characteristics and available carbohydrate content of smooth bromegrass. Agron. J. 60:375-379.
Rehm, G.W., W.J. Moline, and E.J. Schwartz, 1972. Response of seeded mixture of warm-season prairie grasses to fertilization. J. Range Manage. 25:452-456.

Rehm, G.W., R.C. Sorenson, and W.J. Moline. 1976. Time and rate of fertilizer application for seeded warm-season and bluegrass pastures. 1 . Yield and botanical composition. Agron. J. 68:759-764.

Steele, R.G.D., and J.H. Torrie. 1980. Principles and procedures of statistics. 2nd ed., McGraw-Hill Book Co., New York.

Vogel, W.G., and A.J. Bjugstad. 1968. Effects of clipping on yield and tillering of little bluestem, big bluestem, and indiangrass. J. Range Manage. 21:136-140.

Warnes, D.D., L.C. Newell, and W.J. Moline. 1971. Performance evaluation of some warm-season prairie grasses in Nebraska environments. Univ. Nebraska Agr. Exp. Sta. Bull. 241.

White, L.M. 1973. Carbohydrate reserves of grasses: A review. J. Range Manage. 26:13-18. 